\title{
A Disease of Finnock Due to Vibrio anguillarum
}

\author{
BY ISABEL W. SMITH \\ Department of Agriculture and Fisheries for Scotland, Marine Laboratory, Aberdeen
}

(Received 10 August 1960)

\section{SUMMARY}

A disease of finnock (immature Salmo trutta) is described. The causal organism was found to be a Gram-negative, motile, curved rod which was also pathogenic to eels, perch, plaice and saithe. On comparison with other pathogenic vibrios from fish it was apparent that the organism was a variant of Vibrio anguillarum; the name $V$. anguillarum type $\mathrm{C}$ is suggested for it.

\section{INTRODUCTION}

Vibrio anguillarum has long been known to be responsible for red disease of eels, but the descriptions of the organism are various and incomplete, and it has been omitted from Bergey's Manual of Determinative Bacteriology, 7th ed. Nybelin (1935) collected and classified all the strains available at that time, and it is his description which will be used here for comparative purposes.

A disease of young Pacific salmon held in sea-water ponds was reported by Rucker, Earp \& Ordal (1954) as due to a marine species of Vibrio. The fish develop extensive haemorrhages in the muscle and internal organs, and the disease which begins in April or May when the temperature reaches about $50^{\circ} \mathrm{F}$. continues throughout the summer. Hoshina (1956) described a disease of rainbow trout which occurred from late autumn till spring in Japan. It affected both young fish and adults, and was characterized by the production of boil-like lesions or haemorrhages in the muscle. In 1957 Hoshina gave a fuller description of the causal organism which he named $V$. piscium var. japonicus. Rucker (1959) cited various outbreaks of disease due to Vibrio spp. in Pacific salmon, rainbow trout and steel head trout. The organism was found to be different from $V$. comma and was not pathogenic to warm-blooded animals.

Smith (1959) reported an outbreak of disease in finnock in Scotland and stated that it was due to a Vibrio species. The purpose of this paper is to describe the organism isolated from these finnock and by comparison with other similar organisms to show that it is $V$. anguillarum.

\section{SPECIMENS EXAMINED}

During the 6-year period (1954-59) 15 finnock and one sea trout were examined (Table 1).

The dead fish were usually found in late summer or early autumn and always in the tidal part of the river. It was also evident that no one sign of disease was common to all the specimens, but the same organism was isolated in every case. Very 
often this organism grew in pure culture from the spleen, liver, kidney, heart blood and, sometimes, muscle. Sections were also examined but no consistent pathological change was revealed.

The same organism was isolated from a salmon found dead in the River Foyle in August 1959 (Edwards, O'Kelly, Napier \& Fletcher, 1960) and the disease was confirmed in finnock and sea trout of the River Ythan as well as in finnock from the River Dee in the summer of 1960.

Table 1. Specimens examined

\begin{tabular}{|c|c|c|c|c|}
\hline \multirow[b]{2}{*}{ Date } & \multicolumn{4}{|c|}{ No. of specimens } \\
\hline & Source & seen & examined & External appearance \\
\hline September 1954 & $\begin{array}{l}\text { River Dee, George VI } \\
\text { Bridge }\end{array}$ & 3-4 & $\mathbf{1}$ & $\begin{array}{l}\text { Right pectoral fin con- } \\
\text { gested; vent } \\
\text { haemorrhagic }\end{array}$ \\
\hline September 1955 & Cowie Burn & $1^{*}$ & 1 & $\begin{array}{l}\text { Vent distended; } \\
\text { small abrasion on } \\
\text { left operculum }\end{array}$ \\
\hline August 1957 & $\begin{array}{l}\text { River Dee, Pots and } \\
\text { Fords Fishings }\end{array}$ & c. 30 & $\mathbf{1}$ & $\begin{array}{l}\text { Vent haemorrhagic; } \\
\text { haemorrhagic area } \\
\text { on left flank }\end{array}$ \\
\hline August 1958 & River Dee, Victoria Bridge & c. 20 & 11 & $\begin{array}{l}\text { Varied from no sign of } \\
\text { disease to congestion } \\
\text { of fins, haemorrhage } \\
\text { of vent and haemor- } \\
\text { rhagic areas on flanks }\end{array}$ \\
\hline July 1959 & River Dee, Torry Beach & 2 & 2 & $\begin{array}{l}\text { Haemorrhagic swell- } \\
\text { ing on right flank of } \\
\text { one and right shoulder } \\
\text { of the other }\end{array}$ \\
\hline
\end{tabular}

\section{DESCRIPTION OF THE ORGANISM}

(All tests carried out at $\mathbf{2 2}^{\circ}$ unless otherwise stated.)

Morphology. The organism is a small Gram-negative $\operatorname{rod}(2-2.5 \mu \times 1 \mu)$ with a tendency to be curved, especially when direct smears or sections from fish are examined. It is motile by a polar flagellum, non-sporing, non-acid-fast and noncapsulate. Cultures on sea-water agar for 6 days or more show a variable number of oval bodies. These when examined in the phase-contrast microscope appear to have polar granulations. They are similar to the bodies mentioned by Liston (1955) in his description of gut group vibrios.

Growth on nutrient agar plate. Colonies are round, raised, mucoid, translucent and greyish yellow in colour. This organism is non-luminous.

Growth on sea-water agar plate. Colonies are round, raised, translucent but whiter than on nutrient agar. They are also of a more watery consistency.

Growth on nutrient agar slope. Raised mucoid, translucent, greyish yellow, tending to coalesce if growth is heavy.

Growth on nutrient agar stab. On the surface there was a spreading shiny mucoid growth and down the line of the stab there was a sharply defined area of growth. This showed the organism was a facultative anaerobe. 
Growth on blood agar. The organism does not produce haemolysis on horse blood agar.

Growth in nutrient broth. A turbidity develops overnight and this is followed by the production of a pellicle and formation of a deposit. This deposit becomes viscid later.

Growth on Loeffler's serum slope. The organism grows as a smooth, yellow, shiny layer. The serum is liquefied.

Growth on potato slope. On alkaline potato slope the growth is smooth, shiny and yellow.

Biochemical reactions. The organism produces acid but no gas from glucose, fructose, sucrose, maltose, trehalose, starch, dextrin, glycogen, mannitol, sorbitol; slight acid but no gas from galactose and no acid or gas from arabinose, rhamnose, xylose, lactose, cellobiose, raffinose, inulin, glycerol, dulcitol, inositol, amygdalin and salicin. When tested by Hugh \& Leifson's (1953) method the organism was found to belong to Group III $a$, i.e. anaerogenic fermenter. It is methyl red negative, produces acetylmethylcarbinol; does not produce indole; does not grow on Koser's citrate medium; does not produce hydrogen sulphide on ZoBell's medium; produces catalase on nutrient agar; reduces nitrate to nitrite; liquefies gelatin but has no action on filter-paper. In litmus milk a clot is produced and this is followed by proteolysis and reduction.

Table 2. Pathogenicity experiments

\begin{tabular}{|c|c|c|c|c|}
\hline Fish & No. & $\begin{array}{l}\text { Route of } \\
\text { injection }\end{array}$ & $\begin{array}{l}\text { Time } \\
\text { to die } \\
\text { (days) }\end{array}$ & External symptoms \\
\hline Finnock & $\mathbf{3}$ & intraperitoneal & $1-6$ & $\begin{array}{l}\text { Two showed hamorrhage of the vent; one } \\
\text { showed no external symptoms }\end{array}$ \\
\hline Finnock & $\mathbf{1}$ & intramuscular & $\mathbf{2}$ & Inflammation of muscle at site of injection \\
\hline Eels & 4 & intramuscular & 2-7 & $\begin{array}{l}\text { Haemorrhagic swelling at site of injection } \\
\text { and congestion of muscle }\end{array}$ \\
\hline Brown trout & $\mathbf{2}$ & intraperitoneal & $4-6$ & None \\
\hline Perch & $\mathbf{2}$ & intraperitoneal & $\mathbf{2}$ & None \\
\hline Plaice & $\mathbf{1}$ & intramuscular & 22 & $\begin{array}{l}\text { Swollen haemorrhagic area about the size } \\
\text { of a penny with a bluish black centre. } \\
\text { Haemorrhage in peripheral muscle }\end{array}$ \\
\hline aithe & 2 & intraperitoneal & 2-6 & $\begin{array}{l}\text { One showed no symptoms but the other de- } \\
\text { veloped a greyish area on its dorsal surface. }\end{array}$ \\
\hline
\end{tabular}

In all cases the organism was re-isolated after death but in no case was it found in an inoculated or uninoculated control.

Reaction to antibiotics. Evans's 'Senstests' were used. The organism was resistant to 2.5 i.u. penicillin but sensitive to $10 \mu \mathrm{g}$. terramycin. It was also sensitive to the vibriostatic agent 0-129 (2-4-diamino-6-7-di-isopropyl pteridine).

Metabolic properties. When the tap water used to make up peptone water was replaced completely or partially by sea water, the resulting growth was increased and appeared optimal when the concentration of salt in the medium was approximately $2 \%$. The organism grew slowly at $5^{\circ}$ and at $34^{\circ}$ but not at $37^{\circ}$. On salt containing media it grew better at $22^{\circ}$ than at $15^{\circ}$, but on ordinary 
media the final growth was more or less equal at $15^{\circ}$ and $22^{\circ}$. It grows from pH 6.0 to 9.0 with an optimum at 6.8. All these results are based on nephelometer readings. The organism will withstand heating to $40^{\circ}$ for $10 \mathrm{~min}$. but not to $45^{\circ}$ for the same time.

Pathogenicity. Table 2 shows that the organism kills five species of fish including freshwater anadromous, catadromous and marine species.

\section{DISCUSSION}

When this organism is classified according to Skerman (1957) it is found to belong to the family Vibrio if it is treated as a curved rod or to the Pseudomonas family if a straight one. Haynes \& Burkeholder (1957) state that the distinction of the straight rods of the Pseudomonas from the curved rods found in Vibrio is difficult as the curvature of the organism sometimes depends on the medium employed. It has, however, been found that the pseudomonads are oxidative in their action on carbohydrates while the vibrios are fermentative (Hugh \& Leifson, 1953). This organism is fermentative, i.e. it can produce acid from carbohydrates under anaerobic conditions so that on this criterion it should belong to the Vibrio genus. In addition, it is sensitive to the 0-129 which Shewan, Hodgkiss \& Liston (1954) state is a vibriostatic agent. This is further evidence that the organism is a Vibrio species.

For comparison the following cultures which had been isolated from diseased fish were obtained and examined.

(1) Vibrio anguillarum, National Collection of Marine Bacteria No. 6 (Torry Research Station, Aberdeen), isolated by Bagge \& Bagge (1956) from diseased codling in Denmark.

(2) V. piscium var. japonicus isolated by Hoshina (1956) from rainbow trout in Japan.

(3) V. ichthyodermis isolated by Hodgkiss \& Shewan (1950) from a plaice. This was initially called Pseudomonas ichthyodermis but the authors now consider it to be a Vibrio.

Vibrio anguillarum when injected intramuscularly into eels caused death in 2-6 days. It produced haemorrhage at the site of inoculation in two, swelling and congestion in the third and no symptoms in the fourth. The organism was reisolated however from them all, and in every case was found in sections of the spleen, liver or muscle. Intramuscular injection of perch gave rise to swellings and the perch died in 6-10 days. The organism was re-isolated from one and found in liver and muscle sections. Trout also succumbed to intraperitoneal injection in 16-21 days. The peritoneum of one was distended and contained much reddish brown fluid while the vent of the second was slightly distended and haemorrhagic. The organism was re-isolated after death and observed in sections of muscle of both trout.

Neither Vibrio piscium var. japonicus nor V. ichthyodermis was pathogenic for eels but both killed one of four trout inoculated intraperitoneally. In both these cases the organism was re-isolated. This low pathogenicity may well be due to the fact that these organisms have been in vitro culture for some considerable time.

The above three cultures were also studied morphologically and biochemically, and were found to be very similar to the organism isolated from the finnock. 
Vibrio anguillarum differed from the finnock culture only in its ability to ferment arabinose, glycerol and cellobiose and its inability to ferment starch. It produced indole and grew on Koser's citrate medium. V. piscium var. japonicus differed in its action on arabinose, starch inositol and cellobiose and $V$. ichthyodermis by its action on sorbitol, glycerol, starch and cellobiose, its inability to produce acetylmethylcarbinol and its ability to produce indole.

The descriptions of Vibrio anguillarum in the literature vary to some extent, but Nybelin (1935) described $V$. anguillarum as a Gram-negative curved bacillus which was actively motile, non-sporing and non-capsulate. It liquefied gelatin in a similar manner to the cholera bacillus, produced acid but no gas from glucose or maltose, did not produce hydrogen sulphide, had no reducing properties, was haemolytic (only a few strains examined); and was a halophile. He subdivided this species into two subtypes $\mathbf{A}$ and B. A was able to produce acid but no gas from sucrose and mannitol and to produce indole, whereas $B$ had no action on these sugars and did not produce indole. Bagge \& Bagge (1956) describe their isolate as $V$. anguillarum type $A$ on this basis.

Hoshina (1957) ascribed the name Vibrio piscium var. japonicus to the organism he isolated from rainbow trout as he thought it resembled the organism $V$. piscium which David (1927) had isolated from carp. It seems, however, that it is more likely to be a variant of $V$. anguillarum as its growth characteristics are almost identical with those of $V$. anguillarum, and it does not produce indole or hydrogen sulphide to any great extent (I could find neither), whereas $V$. piscium produces them both; lastly Hoshina's culture and $V$. anguillarum both produce acid but no gas from sugars and reduce nitrates to nitrites, while $V$. piscium can neither ferment carbohydrates nor reduce nitrates. It would therefore seem that this organism would be more appropriately named $\boldsymbol{V}$. anguillarum.

Likewise the organism described here falls into Nybelin's general classification except for the haemolysis of rabbit blood which was not studied and the reducing properties which this organism has. It appears, however, that this organism is intermediate between A and B. Nybelin (1935) did study such a strain. He obtained it from Schäperclaus who isolated it at Lübeck in 1932. This strain was able to produce acid from both sucrose and mannitol but could not produce indole. Nybelin considered it unnecessary to postulate a third type to cover this strain, as it might have been a weak indole producer, but the strain from finnock and that of Hoshina seem to be identical with the Lübeck strain and so should be called V. anguillarum type $\mathbf{C}$.

No attempt has been made to study the antigenic structure of the strains considered here, as previous workers have shown that the structure is complex, and Nybelin'(1935) found that cross-reactions rarely occurred in organisms isolated from different epizootics.

Strains of this organism have been lodged with the National Collection of Marine Bacteria at Torry Research Station, Aberdeen.

The author wishes to express her thanks to Mr K. A. Pyefinch for his interest and encouragement, to Miss E. F. M. Greig for her valuable technical assistance, and to Messrs F. G. T. Holliday, W. D. Irvine, G. G. J. Smart, R. Steven and interested anglers for the supply of specimens. 


\section{REFERENCES}

BAGge, J. \& BAgGe, O. (1956). Vibrio anguillarum som årsag til ulcussygdom hos torsk (Gadus callarias Linné). Nord. Vet. Med. 8, 481.

David, H. (1927). Ubber eine durch cholerä̈hnliche Vibrionen hervorgerufene Fischseuche. Zbl. Bakt. (Abt. 1. Orig.), 102, 46.

Edwards, J., O'Knily, E., Napier, J. G. \& Fletcher, M. J. (1960). Eighth Annual Report, Foyle Fisheries Commission, Dublin, p. 8.

HaYNes, W. C. \& Burkeholder, W. H. (1957). Genus I Pseudomonas Migula, 1894. In Bergey's Manual of Determinative Bacteriology, 7 th edition, p. 89. London: Baillière, Tindall and Cox Ltd.

Hodgkiss, W. \& Shewan, J. M. (1950). Pseudomonas infection in a plaice. J. Path. Bact. 62,655 .

Hosmina, T. (1956). An epidemic disease affecting rainbow trout in Japan. J. Tokyo Univ. Fish. 42, 15.

Hoshina, T. (1957). Further observations on the causative bacteria of the epidemic disease like furunculosis of rainbow trout. J. Tokyo Univ. Fish. 43, 59.

Hugr, R. \& LeIfson, E. (1953). The taxonomic significance of fermentative versus oxidative metabolism of carbohydrates by various Gram negative bacteria. J. Bact. 56, 24.

ListoN, J. (1955). A quantitative and qualitative study of the bacterial flora of skate and lemon sole trawled in the North Sea. Ph.D. Thesis, Aberdeen University.

NYBELIN, O. (1935). Untersuchungen über den bei Fischen krankheits-erregenden Spaltpilz Vibrio anguillarum. Medd. Untersökn.Anst. Sötvattensfisk. Stockh. no. 8.

Rucker, R. R., EARP, B. J. \& ORDal, E. J. (1954). Infectious diseases of Pacific salmon. Symposium on Fish Diseases. Trans. Amer. Fish. Soc. 83, 297.

RuCKER, R. R. (1959). Vibrio infections among marine and fresh water fish. Progr. Fish. Cult. 21, 22.

Shewan, J. M., Hodgkrss, W. \& Liston, J. (1954). A method for the rapid differentiation of certain non-pathogenic, asporogenous bacilli. Nature, Lond. 173, 208.

Skerman, V. B.D. (1957). A key for the determination of the generic position of organisms listed in the manual. In Bergey's Manual of Determinative Bacteriology, 7th edition, p. 987. London: Ballière, Tindall and Cox Ltd.

SmrrH, I. W. (1959). Vibrio spp. in finnock from the Aberdeenshire Dee. Nature, Lond. $183,1409$. 